\title{
Using methane biological oxidation to partially finance sustainable waste management systems and closure of dumpsites in the Southern Mediterranean region
}

\author{
Tarek Abichou ${ }^{1}$
}

Published online: 29 April 2020

(c) The Author(s) 2020

In 2014, the European Environment Agency (EEA) and the United Nations Environment Programme/Mediterranean Action Plan (UNEP/MAP) published a joint report entitled "Horizon 2020 Mediterranean: Toward shared environmental information systems". This report stated that because of the large coastal population and human activities bordering the Mediterranean Sea, waste management represents a significant pressure on the coastal and marine environments of the region (EEA-UNEP/MAP 2014). Deficiencies in solid waste management systems, especially in the European Neighborhood Policy-South (ENP-South) countries, are responsible for aesthetic pollution and contribute to the problem of elevated levels of beach and marine litter. The report adds that although waste generation per capita in the ENP-South is lower than European countries, many coastal cities in the ENP-South region still rely on unregulated open dumps. Additionally, municipal solid waste collection rates in these countries vary from zero (no collection) in some countries to near-complete collection in others. These conditions lead to inadvertent release of litter and garbage into coastal and marine waters and contribute to the marine litter problem in the Mediterranean Sea (UNEP 2009). Therefore, marine pollution in the Mediterranean region cannot be addressed before assisting the ENP-South countries in the management of their solid waste systems. A methodology is proposed to allow coastal communities within the ENP-South region to close their open dump sites and reduce the greenhouse gas emissions from these dump sites, using methane bio-oxidation. The avoided methane emissions, acquired via the closing of dump sites, are then converted into carbon credit offsets to be used as a vehicle to finance

Tarek Abichou

abichou@eng.famu.fsu.edu

1 Department of Civil Engineering, FAMU-FSU College of Engineering, Florida State University, Tallahassee, FL, USA waste management systems, including the adequate closure of these pollution causing dump sites.

Methane oxidation could be used as a means to reduce methane emissions from soil covers installed on open dumps. Any closure plan of dumpsites requires the installation of a cover system. The obvious purpose of installing a cover system is to stop people from continuously using the site as an open dump. But more importantly, the installation of a cover system minimizes the risk of infectious diseases carried by animals and controls infiltration of rainwater into the waste mass. With a cover system installed, the risk of ground contamination is reduced by the reduction in rainwater infiltration. Additionally, the risk of landfill fires will be eliminated since the pathway of oxygen to the waste mass is cut off by the cover system. Closed dumpsites will also reduce their contribution to marine litter especially in coastal regions. In terms of greenhouse gas emissions, open dumpsites will account for $8-10 \%$ of the global anthropogenic greenhouse gas emissions by 2025 (ISWA 2016). Therefore, in developing countries, discussion on closing or alternatively upgrading open dumps is a key option to reduce greenhouse gas emissions. For developing countries, such as countries on the southern coast of the Mediterranean Sea, soil covers are more cost effective, when compared to other soil/geosynthetic options, because they use locally available materials and can be easily constructed by local contractors.

The issue of open dumping of solid waste has been a global challenge for many years. During the 6 months period from December 2015 to June 2016, more than 750 deaths were related to poor waste management in dumpsites (International Solid Waste Association (ISWA) 2016). Therefore, open dumpsites represent a global health and environmental emergency (ISWA 2016). In the report entitled, "A Roadmap for closing Waste Dumpsites: The World's most Polluted Places", ISWA also stated that even though closing of dumpsites is a central component for the Sustainable Development Goals (SDGs), it is a financial challenge for most developing 
countries. In other words, the main barrier for closing dumpsites in poor countries in general and in the ENP-South in particular, is mainly who is going to pay for it.

\section{Solid waste-related methane emissions and the global picture}

Methane $\left(\mathrm{CH}_{4}\right)$ has become a target for greenhouse gas emissions reduction due to its relatively short life-time in the atmosphere, for 9-10 years, and its higher effectiveness as a greenhouse gas (RWMO 1998; IPPC 2001). In the atmosphere, methane represents less than $1 \%$ of the amount of carbon dioxide, but it is responsible for $25 \%$ of the atmosphere's heat absorption, which makes methane a much "stronger" or more "potent" greenhouse gas (WMO 1998; IPPC 2001). The relatively short lifetime of methane in the atmosphere means that the effect of mitigation efforts focused on methane emission reduction would be rapidly observed in the atmosphere. Finally, reducing methane emissions is easier than reducing carbon dioxide because there are less economic interests at stake, and because methane can be converted to usable energy.

Waste management is estimated to be the third largest source of methane emission in the United States (USEPA 2014). In Europe, an estimated 30\% of anthropogenic methane emissions is by landfills (EEA 2014). Stern and Kaufmann (1996) stated that around $12 \%$ of worldwide methane emissions is caused by the decomposition of waste within landfills. Furthermore, emission reduction from landfills is amongst the most feasible and cost-effective measures to reduce anthropogenic GHG emissions (Oonk 2010). Although some modern landfills capture and use much of the generated methane gas, this is not the case at the global level, especially in the developing world where solid waste is disposed in open dumps. Methane emissions from solid waste disposal sites were either considered as "point sources" or occur in localized areas, which makes them good candidates for many international GHG emission reduction programs.

Several international programs have existed to target the reduction of methane emissions from solid waste management activities. For instance, in 2004, the US Environmental Protection Agency (USEPA) started the Global Methane Initiative (GMI), formerly known as the Methane to Market Program. GMI works with the United Nations Economic Commission for Europe (UNECE) and the Climate and Clean Air Coalition (CCAC), to fund projects associated with collection of methane in landfills or open dumps as a measure to reduce global methane emissions. Under the Clean Development Mechanism (CDM), solid waste-related methane emissions were also considered as easy targets for greenhouse emission reduction projects. The World Bank, among others, has funded a plethora of projects in many countries to collect and flare landfill gas under the CDM protocol. Despite these programs, many of such projects failed to achieve the emission reduction forecasted under the $\mathrm{CDM}$ or other funding formulation, mainly due to: (1) the over-estimation of the methane generation potential during the planning phase of these projects, and (2) the inadequate in-field performance of installed landfill gas collection systems, especially in developing countries. In other words, not enough landfill gas and not enough methane gas were generated or collected, and, therefore, not enough carbon offsets are obtained by flaring of the collected gas. The CDM funding protocol did not provide enough carbon credit offsets to cover the costs of these projects, which always included the installation of an expensive gas collection system. The volume of collected gas in these projects was not as large as that anticipated and more importantly, the quality of the collected gas was not always suitable for high temperature flaring (thermal destruction of methane), typically used to obtain the carbon credit offsets.

The quantity and quality of the collected landfill gas are important because, once methane concentrations fall below $35-40 \%$ and the total production rates are below 30 to $50 \mathrm{~m}^{3}$ per hour, the treatment of landfill gas in combined heat and power plants become technically and economically not feasible (Haubrichs and Widmann 2006). When methane concentrations reach about 20-25\%, and landfill gas flow rates dip below $10-15 \mathrm{~m}^{3}$ per hour, the most suitable treatment method becomes high temperature flaring. Below these values, the treatment of poor quality landfill gas, typical of open dump sites, becomes more expensive and complex (HuberHumer et al. 2008). One of the most promising options under these conditions is the passive collection and bio-oxidation of methane in soils covers.

\section{Methane biological oxidation in landfill soil cover environment}

Soil covers are used to reduce the quantity of water that infiltrates into waste deposits at landfills. Reducing the volume of infiltrating water reduces the amount of leachate that is generated and the risk of groundwater contamination. Generally, soil covers are designed with low saturated hydraulic conductivity materials such as compacted clay barriers, geosynthetic clay liners (GCLs), or flexible membrane liners (FMLs). This design philosophy is often referred to as "raincoat", barrier, or "umbrella" approach. Barrier type covers, have been shown to lose their impermeable qualities over time because of the influence of climate variations on the integrity of the liner system. One type of an alternative is to design landfill covers using a water balance approach to exploit the water storage capacity of finer textured soils and the water removal 
capability of vegetation. This type of cover is referred to as an evapotranspiration or ET cover or water balance cover. Landfill ET covers can also be described as vegetated soil landfill covers with the primary purpose of controlling infiltration of precipitation into the waste zone through water balance mechanisms instead of the resistive mechanism employed by conventional barrier covers (Albright et al. 2010). The variables that can be manipulated during design of ET covers which are vegetation, soil properties, and thickness of soil layers. An appropriate combination of these variables is needed for the local climate to assure an appropriate design (Ankeny 2000). Therefore, the key in designing ET covers is to provide enough storage during vegetation dormant months so that the stored water can be released during the growing season of the vegetation. These types of cover have been widely used especially in arid and semi-arid regions, similar to the Mediterranean region (Albright et al 2010).

In general, the top layers of ET covers are designed with soils that can develop a widely distributed rooted zone with high organic content. Roots and vegetation have been also known to be suitable media for a natural bacteria called "Methanotrophs". Methanotrophic bacteria are known to oxidize landfill gases and specifically methane $\left(\mathrm{CH}_{4}\right)$ to carbon dioxide $\left(\mathrm{CO}_{2}\right)$ because they possess the $\mathrm{CH}_{4}$ mono-oxygenase enzyme, which enables them to use $\mathrm{CH}_{4}$ as a source of energy and as a major carbon source. Several previous studies on landfill $\mathrm{CH}_{4}$ oxidation in soil have demonstrated the ability of methane oxidation as a mechanism to reduce $\mathrm{CH}_{4}$ emissions from landfill surfaces (Bogner et al. 1995; Börjesson and Svensson 1997; Kjeldsen et al. 1997; Scheutz et al. 2003; Huber-Humer et al. 2008; Bogner and Spokas 1993; Abichou et al. 2008, 2009, 2010, 2011, 2015a, 2016; Yuan et al. 2009). However, the capacity of landfill cover soil to oxidize $\mathrm{CH}_{4}$ depends on both the physical and the chemical properties of landfill cover materials such as soil type, moisture content, density, organic and nutrient content, etc. Additionally, environmental conditions such as temperature and precipitation can also impact the performance of landfill cover soils in terms of oxidizing $\mathrm{CH}_{4}$. In addition to dependence on soil and climate types, methane oxidation has been reported to also depend on the magnitude of methane loading from the waste mass into the soil profile. Because of these reasons, mathematical and numerical models have been developed to estimate methane oxidation in landfill soil covers by simulating water-heat-gas transport and biological oxidation in soil under dynamic climatic conditions.

One example of such models was developed by a research team at Florida State University (LandSEM Model). LandSEM combines water and heat flow with a gas transport and oxidation in soil profiles under any climatic conditions and under different methane loading conditions. The latest version of the model was bundled via a graphical user inter-face. The new LandSEM model comprises four major modules:

- A climate module which generates daily minimum and maximum air temperature along with daily rainfall based on the landfill site's geographical location.

- A soil property generation module which generates soil properties, e.g., saturated hydraulic conductivity, porosity and methane oxidation capacity based on a built-in database of soil property data from the literature;

- A soil water content and temperature simulation module which uses the landfill site location, soil texture information and the climate generation data developed in the first two steps and then predicts the daily soil moisture and temperature at any depth of the soil cover profile for an average climatic year;

- A core computational module, based on Abichou et al. (2009, 2008) and Yuan et al. (2009), which simulates the concentration and flux of the gas components including methane in the landfill cover soil profile.

\section{Using bio-oxidation to finance the closing of a hypothetical garbage dump in Tunisia}

Abichou et al. (2009, 2010) and Kormi et al. (2018) developed an estimation technique to estimate the extent of methane biological oxidation, in any given soil profile installed on: (1) landfills or dumpsites across the climatic zones of the Mediterranean basin, (2) ET covers under the different climates in California, and (3) ET covers, referred to as phyto-Cover, to be constructed across different ecozones of Australia. In all of these studies, LandSEM was used to develop correlations between percent methane oxidation, and methane loading flux into a given soil profile under different microclimatic conditions.

Kormi et al. (2018) divided the Mediterranean basin into four sub-climates or sub-regions. For the purpose of estimating methane oxidation for ET covers on dump sites in the Mediterranean Basin, seventeen large cities and their locations were selected. The seventeen locations were assumed to be representative of regional microclimates within each of the sub-regions of the Mediterranean basin. For instance, Alger, Tunis, Tripoli, and Alexandria were selected to represent the southern region of the Mediterranean. Average daily climatic conditions in each location were obtained by the climate generation module, embedded in LandSEM using the latitude and the longitude along with the average altitude of the selected city as the main input for the climate generator module in LandSEM. Several simulations were performed at each of the seventeen locations.

A 1-m-thick ET cover was assumed to be constructed with sandy loam (USDA Classification) and was modeled 
as the default soil cover for all seventeen locations. The soil gradation (percent sand, silt, clay) was used by the soil property generation module, embedded in LandSEM, to generate the soil hydraulic and transport properties needed to simulate water, heat, and gas transport through the soil. The developed correlations were then applied to an example dump near the city of Tunis, Tunisia. For the purpose of this example, a four hectare municipal solid waste dump located near the city of Tunis was assumed. The dump was also assumed to accept 500 tons per day of municipal solid waste for 5 years (2010-2015). The ET cover was modeled to be installed in 2016. Results of the simulations suggested that methane emissions from the hypothesized open dump are around 350 tons per year in 2010, reach a peak of 1600 tons per year in 2013, and start to decrease exponentially to reach 200 tons per year by 2061 .

The percent oxidation is then calculated as the difference between the emissions (with no closure of the example dumpsite) and the emissions estimated with the installation of the 1-m-thick soil cover. This difference is considered to represent the yearly mass reduction in methane emission from the assumed waste dump due to the installation of the soil cover. The estimated yearly reduction in methane emissions was then converted to tons of $\mathrm{CO}_{2}$ equivalent. The price of carbon credit offsets was assumed to be $\$ 10$ per ton (Siikamäk et al. 2012). The simulations of the hypothetical Tunis dump indicated that the placement of 1-m-thick soil cover on the assumed dump, near Tunis can generate $\$ 80,000$ carbon credit during the first year of placement of the soil cover. The estimated carbon credit decreases to $\$ 40,000$ after 46 years of installation of the cover. These potential numbers are very encouraging in terms of motivating developing countries to close their waste dumps using soil caps.

Open Access This article is licensed under a Creative Commons Attribution 4.0 International License, which permits use, sharing, adaptation, distribution and reproduction in any medium or format, as long as you give appropriate credit to the original author(s) and the source, provide a link to the Creative Commons licence, and indicate if changes were made. The images or other third party material in this article are included in the article's Creative Commons licence, unless indicated otherwise in a credit line to the material. If material is not included in the article's Creative Commons licence and your intended use is not permitted by statutory regulation or exceeds the permitted use, you will need to obtain permission directly from the copyright holder. To view a copy of this licence, visit http://creativecommons.org/licenses/by/4.0/.

\section{References}

Abichou T, Yuan L, Chanton J (2008) Estimating methane emission and oxidation from earthen landfill covers. In Geocongress 2008: geotechnics of waste management and remediation (GSP), New Orleans, LA, 9-12 March, pp 80-87
Abichou T, Mahieu K, Yuan L, Chanton J, Hater G (2009) Effects of compost biocovers on gas flow and methane oxidation in a landfill cover. Waste Manag 29(5):1595-1601

Abichou T, Johnson T, Mathieu K, Chanton J, Romdhane M, Mansouri I (2010) Developing a design approach to reduce methane emissions from California landfills. In: Fratta D, Muhuntan B, Pupala A (eds) Geotechnical special publication No 199. ASCE, Baltimore

Abichou T, Mahieu K, Chanton J, Romdhane M, Mansouri I (2011) Scaling methane oxidation: from laboratory incubation experiments to landfill cover field conditions. Waste Manag 31(5):978-986

Abichou T, Kormi T, Wang Ch, Chanton JP, Green R, Escobar F (2015a) A novel approach to estimate methane oxidation in interim landfill covers across the USA. Int J Environ Waste Manag 15(4):309-326

Abichou T, Kormi T, Yuan L, Johnson T, Francisco E (2015b) Modeling the effects of vegetation on methane oxidation and emissions through soil landfill final covers across different climates. Waste Manag 36:230-240

Abichou T, Kormi T, Marsh A, Wang C (2016) Phytocaps for landfill emission reduction in Australia, USA. In: Geo-Chicago 2016, Chicago, USA, 14-18 August, pp 222-231

Albright WH, Benson CH, Waugh WJ (2010) Water balance covers for waste containment, principles and practice. ASCE Press, Reston

Ankeny M (2000) Process-based design. Designing and implementing alternative earthen final covers for waste containment facilities, section 2. Department of Engineering Professional Development, University of Wisconsin-Madison

Bogner J, Spokas K (1993) Landfill CH4: rates, fates, and role in global carbon cycle. Chemosphere 26:369-386

Bogner J, Spokas K, Burto E, Sweeney R, Corona V (1995) Landfills as atmospheric methane sources and sinks. Chemosphere 31(9):4119-4130

Börjesson G, Svensson BH (1997) Seasonal and diurnal methane emissions from a landfill and their regulation by methane oxidation. Waste Manag Res 15:33-54

EEA (2014) Annual European Union greenhouse gas inventory 19902011 and inventory report 2014. European Environment Agency, Copenhagen

EEA-UNEP, MAP (2014) Horizon 2020 Mediterranean report: toward shared environmental information systems. EEA technical report No 6/2014. Publications Office of the European Union, Luxembourg

Haubrichs R, Widmann R (2006) Evaluation of aerated biofilter systems for microbial methane oxidation of poor landfill gas. Waste Manag 26(4):408-416

Huber-Humer M, Gebert J, Hilger H (2008) Biotic systems to mitigate landfill methane emissions. Water Manag Res 26:33-46

IPCC (2001) Climate change 2001: the scientific basis. Cambridge University Press, Cambridge

IPCC (2006) IPCC guidelines for national greenhouse gas inventories. In: Eggleston HS, Buendia L, Miwa K, Ngara T, Tanabe K (eds) Institute for global environmental strategies. IPCC, Hayama

ISWA (2016) A roadmap for closing waste dumpsites: The World's most Polluted Places. https://www.iswa.org/fileadmin/galleries/About \%20ISWA/ISWA_Roadmap_Report.pdf. Accessed 1 Nov 2017

Kjeldsen P, Dalager A, Broholm K (1997) Attenuation of methane and nonmethane organic compounds in landfill gas affected soils. J Air Waste Manag Assoc 47:1268-1275

Kormi T, Abichou T, Kout $\mathrm{N}$ et al (2018) Using methane biological oxidation in soil as a tool to finance closure of dumpsites across the Mediterranean Basin. Euro-Mediterr J Environ Integr 3:6. https:// doi.org/10.1007/s41207-017-0044-7

Oonk H (2010) Literature review: methane from landfills. Innovations in Environmental Technologies, $75 \mathrm{p}$

Scheutz K, Kjeldsen P, Chanton J, Blake D, Bogner J (2003) Comparative oxidation and net emissions of $\mathrm{CH} 4$ and selected non- $\mathrm{CH} 4$ organic compounds in landfill cover soils. Environ Sci Technol 37:5150-5158 
Siikama“kia J, Sanchiricoa J, Jardinec S (2012) Global economic potential for reducing carbon dioxide emissions from mangrove loss. PNAS 109(36):14369-14374

Stern D, Kaufmann R (1996) Estimates of global anthropogenic methane emissions 1860-1993. Chemosphere 33:159-176

UNEP (2009) Marine litter: a global challenge. UNEP, Nairobi. http:// wedocs.unep.org/handle/20.500.11822/7787

USEPA (2005) Landfill gas emissions model v.3.02. Available at: http:// www.epa.gov/ttn/catc/dir1/landgem-v302.xls
USEPA (2014) Global mitigation of non-CO2 greenhouse gases: 2010-2030. US Environmental Protection Agency, Washington, DC, USA

WMO (1998) Scientific assessment of ozone depletion, report no. 44. World Meteorological Organization, Washington

Yuan L, Abichou T, Chanton J, Powelson D, De Visscher A (2009) Long term numerical solution of methane transport and oxidation in a compost biofilter. Pract Period Hazard Toxic Radioact Waste Manag 13(3):196-202 